THE RING 34 (2012) DOI 10.2478/v10050-012-0003-2

\title{
MORPHOMETRICS OF CERRADO BIRDS FROM THE RESERVA NATURAL LAGUNA BLANCA \\ (NE PARAGUAY)
}

\author{
Paul Smith, Derek Onley, Emma Northcote-Smith and Karina Atkinson
}

\begin{abstract}
Smith P., Onley D., Northcote-Smith E, Atkinson K. 2012. Morphometrics of cerrado birds from the Reserva Natural Laguna Blanca (NE Paraguay). Ring 34: 51-67.

Morphometric data are provided for 204 individuals of 61 species from the Reserva Natural Laguna Blanca in Departamento San Pedro in north-eastern Paraguay. Measurements were taken according to Svensson (1984). Data for 2 cerrado endemic species, 2 species of global conservation concern and 5 species of national conservation concern are presented. These are the first published biometric data for birds of the Paraguayan cerrado.
\end{abstract}

P. Smith, FAUNA Paraguay, www.faunaparaguay.com, faunaparaguay@gmail.com, Para La Tierra, www.paralatierra.org, paralatierra@ymail.com; D. Onley, E. Northcote-Smith, K. Atkinson, Para La Tierra, www.paralatierra.org, paralatierra@ymail.com

Key words: Reserva Natural Laguna Blanca, cerrado, birds, Paraguay, Para La Tierra, weight, measurements

\section{INTRODUCTION}

Since a paper by Whittle (1927) calling for the publication of more biometric data for birds, very little has been forthcoming on Neotropical birds. The only published data for Paraguayan birds have been based on small samples of just 17 species from the Humid Chaco (Peris 1990) and 38 species from the Dry Chaco (Smith et al. 2008). Here, we present the first biometric data on live birds from the Campos Cerrados of Paraguay, covering a total of 204 individuals of 61 species.

Cerrado is a savanna-type vegetation structure that grows in areas with nutrientpoor soils (Eiten 1972). The habitat is endemic to the Neotropics and stretches across a broad area of central and western Brazil, a small area of north-eastern Bolivia and into the northern Oriental region of Paraguay. Cerrado is the world's most diverse savanna system, yet also one of the most threatened, and is recognised as one of the world's most important biodiversity hotspots (Myers et al. 2000, Conservation Interna- 
tional Online 2011). Although the entire eco-region covers an area of $2031990 \mathrm{~km}^{2}$, only $5.5 \%\left(111051 \mathrm{~km}^{2}\right)$ are officially protected. (Conservation International Online 2011). Large areas of cerrado still remain in Paraguay, but much of it is located within private properties, complicating its effective conservation at the national level (Coconier 2004).

Broadly speaking the cerrado habitat can be split into four categories or "ecotopes": campo limpio (grassy field), campo sucio (grassy and bushy fields with scattered trees), sensu stricto (bushy fields without grass) and cerradón (cerrado dry forest). These ecotopes represent observable trends in habitat types and are not associated with any specific floral communities, which may vary greatly in any given ecotope from one area to another (Eiten 1972, 1978). Flora and fauna species diversity within any given patch of the cerrado is associated with the diversity of ecotopes rather than the total area of habitat (Colli et al. 2002, Nogueira et al. 2005).

The cerrado region was for a long time considered a sub-optimal land for agricultural development, with low-nutrient substrates providing poor yields when compared to nutrient-rich substrates. Although ignored by agriculturists for a long time, innovative studies proved that the addition of phosphorus and lime to soils could considerably improve yields and allow cash crops such as soya to be grown effectively in the region (de Oliveira et al. 2007). Rapidly increasing land prices for "optimal" areas in Brazil and Paraguay contributed to an increased interest in cerrado areas for agriculture and cattle-ranching, and the region now provides more than $70 \%$ of Brazil's beef production (Corrêa 1990). Being a savanna habitat cerrado requires less investment for clearing and lower yields are compensated to some degree by considerably lower costs. A pronounced dry season (April to October) means that fires are part of the normal cycle of the cerrado, and many plants and animals are adapted to regular burns. Irregular or particularly severe fires, as well as uncontrolled man-made burns out of season, can however have a devastating effect on the megafauna (Silveira et al. 1999). As a result, accelerating habitat destruction is the greatest threat to the cerrado and its floral and faunal communities.

\section{STUDY SITE}

Fieldwork was performed at Para La Tierra Biological Station located at Reserva Natural de Laguna Blanca $\left(23^{\circ} 48^{\prime} \mathrm{S}, 56^{\circ} 17^{\prime} \mathrm{W}\right)$ in the cerrado zone of the northeastern Paraguay. The RNLB is a small (815 ha) reserve comprising over 400 ha of near pristine cerrado, a patch of degraded Atlantic forest and some transitional semideciduous humid-dry gallery forest. The four main cerrado ecotopes are present at RNLB and grow on a predominantly sandy substrate. The reserve is based around an eponymously-named lake of 157 ha, which, geologically-speaking, is possibly the only true lake in Paraguay. A basic review of the area, its floral composition and its importance for birds is provided by Guyra Paraguay (2008).

A total of 286 bird species have been recorded at Laguna Blanca, 11 of which are of global conservation concern and 47 of national conservation concern (IUCN 2011). The cerrado of this place is of special interest given the high number of species of 
conservation concern that are known to occur there (Smith et al. 2005, Guyra Paraguay 2008). Laguna Blanca was declared an Important Bird Area PY021 by Birdlife International (Guyra Paraguay 2008) and given official protected status with its declaration as a Reserva Natural in 2010 (Decreto 3893 under Articulo 26 of Protected Areas Law 352/94).

\section{METHODS}

Data were collected during three separate sampling periods: 27 October - 26 November 2005, 9 July - 14 August 2010 and 8-18 January 2011.

Birds were captured using 1 to 7 Japanese mist-nets of 10 to $20 \mathrm{~m}$ total length each, at random scattered sites in the cerrado and transitional forest areas of the reserve. Netting was performed for up to 9 hours each day, with nets closed at night and during periods of rain. Tape luring was used sparingly to assist in the trapping of certain species. Nocturnal birds were captured by means of a powerful spotlight, hand-held torch and a hand net with a wide head diameter. All birds were released after relevant data were collected.

Measurements were taken according to Svensson (1984). The only exception was the use of the minimum chord wing measurement, which does not involve the flattening of the wing against the ruler, measuring the wing parallel to the body from the wing bend to the tip of the longest primary. Measurements were taken with a ruler to the nearest $1 \mathrm{~mm}$ or with callipers to the nearest $0.1 \mathrm{~mm}$. Weights were taken using $100 \mathrm{~g}$ and $1 \mathrm{~kg}$ Pesola spring balances with accuracies of 0.5 and $1 \mathrm{~g}$, respectively. Taxonomy follows FAUNA Paraguay (2011). Global conservation status follows IUCN (2011). National conservation status follows Guyra Paraguay (2005). Categorisation as endemic to the cerrado follows da Silva (1997).

Each species is treated individually in the Results. The following codes are used below: $N$ - number of individuals measured, $C$ - exposed culmen (bill length), $B D-$ bill depth across the middle of nares, $B W$ - bill width across the middle of nares, $H B-$ head + bill length, $T$ - tarsus length, Wing - minimum chord wing measurement, Tail - tail length, Weight - mass in grams.

\section{RESULTS AND DISCUSSION}

Morphometric data are provided for 204 individuals of 61 species (Table 1). Data for 2 cerrado endemic species, 2 species of global conservation concern and 5 species of national conservation concern are presented. Taxonomic and ecological notes relevant to the Reserva Natural Laguna Blanca are included. 
Table 1

Measurements of the birds captured. The following codes are used: $N$ - number of individuals measured, $C$ - exposed culmen (bill length), $B D$ - bill depth across the middle of nares, $B W-$ bill width across the middle of nares, $H B$ - head + bill length, $T$ - tarsus length, Wing - minimum chord wing measurement, Tail - tail length, Weight - mass in grams. For single individuals the values of parameters are given, for 2-4 individuals - ranges of measurements are presented and for $>4$ individuals - ranges, means and standard deviations (in parentheses) are provided. For sexually dimorphic species, measurements are given separately for males and females. In some cases separate data is provided for adults and juveniles. All measurements are presented in millimetres and all masses in grams.

\begin{tabular}{|c|c|c|c|c|c|c|c|c|}
\hline & $C$ & $B W$ & $B D$ & $H B$ & $T$ & Wing & Tail & Weight \\
\hline \multicolumn{9}{|c|}{ Crypturellus parvirostris } \\
\hline$N o$ & 1 & 1 & 1 & 1 & 1 & 1 & 1 & - \\
\hline Value & 17 & 6 & 6 & 28 & 31 & 115 & 45 & - \\
\hline \multicolumn{9}{|c|}{ Porzana albicollis } \\
\hline$N \sigma \sigma$ & 1 & 1 & 1 & 1 & 1 & 1 & 1 & - \\
\hline Value & 29 & 6 & 11 & 26 & 36 & 120 & 78 & \\
\hline \multicolumn{9}{|c|}{ Columbina picui } \\
\hline $\mathrm{N} \sigma \sigma$ & 3 & 3 & 3 & 3 & 3 & 3 & 3 & - \\
\hline Range & $12-13.5$ & $4-4.5$ & $3-5$ & $32-33$ & $16-19$ & $84-87$ & $68.5-76.5$ & - \\
\hline \multicolumn{9}{|c|}{ Columbina talpacoti } \\
\hline$N \sigma \sigma$ & 2 & 2 & 2 & 2 & 1 & 2 & 2 & 2 \\
\hline Value/Range & 13 & $4-6$ & $3-5$ & $33-34$ & 18 & $97-97.5$ & $70.5-71$ & $55-56$ \\
\hline$N$ १ & 3 & 1 & 1 & 3 & 3 & 3 & 3 & 3 \\
\hline Value/Range & 11.6-13.5 & 4 & 4 & $31.5-34.9$ & $16-17.5$ & $91-93$ & $61-65$ & $46-48.5$ \\
\hline \multicolumn{9}{|c|}{ Scardafella squammata } \\
\hline$N \sigma 9$ & 3 & 3 & 3 & 3 & 3 & 3 & 3 & 2 \\
\hline Value/Range & $13-16$ & $4.5-6$ & $4-5$ & $35-36$ & 17.5-19 & $97-100$ & $91-108$ & 58 \\
\hline \multicolumn{9}{|c|}{ Brotogeris chiriri } \\
\hline$N \sigma 9$ & 3 & 3 & 3 & 3 & - & 3 & 3 & 3 \\
\hline Value/Range & 16 & $10-12$ & 15 & $45-48$ & - & $123-130$ & $87-103$ & $70-80$ \\
\hline \multicolumn{9}{|c|}{ Coccyzus melacoryphus } \\
\hline$N \sigma \%$ & 1 & 1 & 1 & 1 & 1 & 1 & 1 & - \\
\hline Value & 23 & 9 & 8 & 44.5 & 28 & 113 & 130.5 & - \\
\hline \multicolumn{9}{|c|}{ Phaethornis pretrei } \\
\hline$N \sigma ?$ & 1 & - & - & - & - & 1 & 1 & - \\
\hline Value & 32 & - & - & - & - & 56 & 76 & - \\
\hline \multicolumn{9}{|c|}{ Hylocharis chrysura } \\
\hline$N$ o 9 & 8 & 7 & 7 & 4 & 3 & 8 & 8 & 3 \\
\hline $\begin{array}{l}\text { Range } \\
\text { Mean (SD) }\end{array}$ & $\begin{array}{c}19-25 \\
1.7(1.75)\end{array}$ & $\begin{array}{c}4-6 \\
4.5(0.76)\end{array}$ & $\begin{array}{c}2-3 \\
2.6(0.45)\end{array}$ & $\begin{array}{c}33-36 \\
-\end{array}$ & $\begin{array}{c}4-4.5 \\
-\end{array}$ & $\begin{array}{c}48-55 \\
51.8(2.43)\end{array}$ & \begin{tabular}{|c|}
$25-34$ \\
$29.9(2.70)$
\end{tabular} & $\begin{array}{c}4-6 \\
-\end{array}$ \\
\hline \multicolumn{9}{|c|}{ Chlorostilbon lucidus } \\
\hline$N o$ & 1 & - & - & - & - & 1 & 1 & - \\
\hline Value & 19 & - & - & - & - & 54 & 27 & - \\
\hline \multicolumn{9}{|c|}{ Nyctibeus griseus } \\
\hline$N \circ ?$ & 2 & - & 2 & 2 & - & 2 & 2 & - \\
\hline Range & $17-21.5$ & - & $5.5-7.5$ & $65-69$ & - & $286-290$ & $162-172$ & - \\
\hline
\end{tabular}




\begin{tabular}{|c|c|c|c|c|c|c|c|c|}
\hline & $C$ & $B W$ & $B D$ & $H B$ & $T$ & Wing & Tail & Weight \\
\hline \multicolumn{9}{|c|}{ Caprimulgus parvulus } \\
\hline$N \sigma \sigma$ & 4 & 4 & 4 & 4 & 4 & 4 & 3 & - \\
\hline Range & $11-14$ & $6.5-7$ & $3-4$ & $38.5-41$ & $17-20$ & $130-144$ & $87-98$ & - \\
\hline$N$ \% & 2 & 2 & 2 & 1 & 2 & 2 & 2 & 1 \\
\hline Value/Range & $11-13$ & $6-8$ & $3-3.5$ & 42 & $15-18.5$ & $130-134$ & $93-106$ & 40 \\
\hline \multicolumn{9}{|c|}{ Hydropsalis brasilianus } \\
\hline$N \sigma \sigma$ & 3 & 3 & 3 & 3 & 3 & 2 & 2 & - \\
\hline Value/Range & $13.5-14.5$ & $7-7.5$ & $3-4.5$ & $46-47$ & $19-20$ & 173-180 & * see text & - \\
\hline \multicolumn{9}{|c|}{ Eleothreptus candicans } \\
\hline$N \sigma \sigma$ & 4 & 4 & 4 & 3 & 4 & 4 & 4 & 2 \\
\hline Value/Range & $11-13.5$ & 8 & $3-4.5$ & $42-47$ & $16-21$ & $137-148$ & $90-106$ & $46-49$ \\
\hline$N$ ९ ९ & 2 & 1 & 2 & 2 & 2 & 2 & 2 & - \\
\hline Value/Range & $12-12.5$ & 8 & 3-3.5 & $41-43.5$ & $16-19$ & 139-145 & $80-88$ & - \\
\hline \multicolumn{9}{|c|}{ Nyctidromus albicollis } \\
\hline$N 9$ & 1 & 1 & 1 & 1 & 1 & 1 & 1 & - \\
\hline Value/Range & 12.5 & 9 & 3.5 & 49 & 31 & 170 & 145 & - \\
\hline \multicolumn{9}{|c|}{ Picumnus cirratus } \\
\hline \begin{tabular}{l|l}
$N ?$ \\
\end{tabular} & 1 & - & - & 1 & - & 1 & 1 & 1 \\
\hline Value & 10.5 & - & - & 26.6 & - & 53 & 31 & 9.5 \\
\hline \multicolumn{9}{|c|}{ Taraba major } \\
\hline$N \sigma$ & 1 & - & - & 1 & 1 & 1 & 1 & 1 \\
\hline Value & 24.3 & - & - & 50.3 & 35.3 & 97 & 82 & 52.5 \\
\hline \multicolumn{9}{|c|}{ Formicivora rufa } \\
\hline$N \sigma$ & 1 & 1 & 1 & 1 & 1 & 1 & - & - \\
\hline Value & 14 & 6 & 5.5 & 32 & 23.5 & 49 & - & - \\
\hline$N ?$ & 1 & 1 & 1 & 1 & 1 & 1 & 1 & - \\
\hline Value & 14 & 4 & 3.5 & 31 & 23 & 46 & 61 & - \\
\hline \multicolumn{9}{|c|}{ Furnarius rufus } \\
\hline$N \sigma \%$ & 5 & 4 & 6 & 5 & 6 & 4 & 5 & 6 \\
\hline Range & $18-20$ & $5-7$ & $5-7$ & $42.5-46$ & $30-34$ & $93-101$ & $64-70$ & $44-47$ \\
\hline Mean $(S D)$ & $19.4(0.89)$ & - & $6.0(0.63)$ & $44.9(1.43)$ & $32.0(1.67)$ & - & $67.4(2.30)$ & $45.2(1.17$ \\
\hline \multicolumn{9}{|c|}{ Synallaxis albescens } \\
\hline$N \circ ?$ & 1 & 1 & 1 & 1 & 1 & 1 & 1 & - \\
\hline Value & 11 & 4 & 4 & 29 & 20 & 51 & 74 & - \\
\hline \multicolumn{9}{|c|}{ Lepidocolaptes angustirostris } \\
\hline$N \sigma ?$ & 2 & 1 & 1 & 2 & 2 & 2 & 2 & 3 \\
\hline Value/Range & $31-33.4$ & 7 & 6 & $54-58.7$ & $17-20.7$ & $92-101$ & $74-79$ & $29-30.5$ \\
\hline \multicolumn{9}{|c|}{ Camptostoma obsoletum } \\
\hline$N \sigma ?$ & 2 & 1 & 1 & 2 & 2 & 2 & 2 & 1 \\
\hline Value/Range & $7.5-9$ & 4 & 3.5 & $24-24.8$ & $15-15.2$ & $52-55$ & $41-48$ & 8.7 \\
\hline \multicolumn{9}{|c|}{ Elaenia chiriquensis } \\
\hline$N \circ ?$ & 1 & 1 & 1 & 1 & 1 & 1 & 1 & - \\
\hline Value & 12 & 6 & 4 & 29 & 18 & 69 & 59 & - \\
\hline \multicolumn{9}{|c|}{ Elaenia parvirostris } \\
\hline$N \sigma \%$ & 3 & 3 & 3 & 3 & 3 & 3 & 3 & - \\
\hline Range & $9-11$ & $5-5.5$ & $3.5-4$ & 29-31 & $17.5-20$ & $69-73$ & 59-59.5 & - \\
\hline
\end{tabular}




\begin{tabular}{|c|c|c|c|c|c|c|c|c|}
\hline & $C$ & $B W$ & $B D$ & $H B$ & $T$ & Wing & Tail & Weight \\
\hline \multicolumn{9}{|c|}{ Elaenia flavogaster } \\
\hline$N \circ 9$ & 6 & 5 & 4 & 6 & 5 & 5 & 5 & 4 \\
\hline Range & $10-11$ & $6-7.5$ & $4.5-6$ & $30.5-33.3$ & $19-21$ & $74-86$ & $66-70$ & $22.5-26$ \\
\hline Mean $(S D)$ & $10.6(0.49)$ & $6.6(0.60)$ & - & $31.4(1.00)$ & $19.8(0.80)$ & $81.2(4.90)$ & $67.8(1.60)$ & - \\
\hline \multicolumn{9}{|c|}{ Euscarthamus meloryphus } \\
\hline$N \circ ?$ & 1 & 1 & 1 & 1 & 1 & 1 & 1 & - \\
\hline Value & 10.5 & 4 & 3.5 & 23 & 22 & 47.5 & 45 & - \\
\hline \multicolumn{9}{|c|}{ Hemitriccus margaritaceiventer } \\
\hline$N \sigma ?$ & 6 & 3 & 3 & 6 & 5 & 5 & 5 & 3 \\
\hline Range & $10-13$ & $4-4.5$ & $3-4$ & $29-30.6$ & $18.4-20$ & $44-51$ & $37-43.5$ & $6.9-9$ \\
\hline Mean $(S D)$ & $11.8(1.06)$ & - & - & $30.1(0.60)$ & $19.2(0.80)$ & $47.4(3.85)$ & $40.4(2.60)$ & - \\
\hline \multicolumn{9}{|c|}{ Myiophobus fasciatus } \\
\hline$N \circ ?$ & 3 & 3 & 1 & 3 & 2 & 3 & 3 & 2 \\
\hline Value/Range & $10-13$ & $6.5-7$ & 4.5 & 29.4-30.9 & $16.6-18$ & $58-65$ & $52-56$ & $10.6-12$ \\
\hline \multicolumn{9}{|c|}{ Cnemotriccus fuscatus } \\
\hline$N$ \%? & 2 & 2 & 1 & 2 & 2 & 2 & 2 & - \\
\hline Value/Range & $11.8-12.5$ & 6.5 & 4 & $32-33$ & $17.6-20$ & 65 & $59-64$ & - \\
\hline \multicolumn{9}{|c|}{ Casiornis rufa } \\
\hline$N$ ○ 9 & 3 & 2 & 1 & 3 & 3 & 3 & 3 & 2 \\
\hline Value/Range & $14.8-16$ & $7.5-8.5$ & 5.5 & $39.3-41.8$ & $20.4-23$ & $80-93$ & $80-84$ & $20-24$ \\
\hline \multicolumn{9}{|c|}{ Myiarchus ferox } \\
\hline$N \sigma ?$ & 1 & 1 & 1 & 1 & 1 & 1 & 1 & - \\
\hline Value & 17.5 & 9 & 6.5 & 44.5 & 23 & 85 & 70 & - \\
\hline \multicolumn{9}{|c|}{ Myiarchus tyrannulus } \\
\hline$N \sigma \%$ & 3 & 3 & 2 & 3 & 3 & 3 & 3 & 2 \\
\hline Range & $18-19$ & $9-9.6$ & $5.5-6.4$ & $45.8-46.7$ & $22-24$ & $92-96$ & $79-89$ & $28-42$ \\
\hline \multicolumn{9}{|c|}{ Pitangus sulphuratus } \\
\hline $\mathrm{N} \propto ?$ & 3 & 3 & 3 & 3 & 3 & 3 & 3 & - \\
\hline \begin{tabular}{|l|} 
Value/Range \\
\end{tabular} & $27-29$ & $11-11.5$ & $9-10$ & $59-60$ & $26-30.5$ & $102-120$ & $75-87$ & - \\
\hline \multicolumn{9}{|c|}{ Myiozetetes similis } \\
\hline $\mathrm{N} \sigma ?$ & 2 & 2 & 2 & 2 & 2 & 2 & 2 & - \\
\hline Range & $14-16$ & $7-8$ & $4.5-5.5$ & $36.5-37.5$ & $21-23$ & $80-90$ & $71.5-75$ & - \\
\hline \multicolumn{9}{|c|}{ Pipra fasciicauda } \\
\hline$N 9$ & 1 & - & - & 1 & 1 & 1 & 1 & 1 \\
\hline Value & 9.5 & - & - & 31.6 & 15.8 & 66 & 32 & 16 \\
\hline \multicolumn{9}{|c|}{ Petrochelidon pyrrhonata } \\
\hline $\mathrm{N} \sigma ?$ & 1 & 1 & 1 & 1 & 1 & 1 & 1 & 1 \\
\hline Value & 9 & 9 & 4 & 33 & 15 & 110 & 45 & 19.5 \\
\hline \multicolumn{9}{|c|}{ Troglodytes aedon } \\
\hline $\mathrm{N} \sigma 9$ & 4 & 5 & 5 & 4 & 4 & 4 & 4 & 4 \\
\hline Range & $13-14.5$ & $4-4.5$ & $3-4$ & $32-36$ & $15-19$ & $48-54$ & $41-42.5$ & $8-22$ \\
\hline Mean $(S D)$ & - & $4.1(0.22)$ & $3.2(0.45)$ & - & - & - & - & - \\
\hline \multicolumn{9}{|c|}{ Turdus rufiventris } \\
\hline$N \sigma ?$ & 1 & - & - & - & 1 & 1 & 1 & 1 \\
\hline Value & 19 & - & - & - & 36 & 116 & 95 & 70 \\
\hline
\end{tabular}




\begin{tabular}{|c|c|c|c|c|c|c|c|c|}
\hline & $C$ & $B W$ & $B D$ & $H B$ & $T$ & Wing & Tail & Weight \\
\hline \multicolumn{9}{|c|}{ Turdus leucomelas } \\
\hline$N \sigma ?$ & 11 & 5 & 5 & 8 & 11 & 11 & 10 & 5 \\
\hline \multirow{2}{*}{$\begin{array}{l}\text { Range } \\
\text { Mean }(S D)\end{array}$} & $18-22$ & $7-8$ & $6.5-7.5$ & $48-51.2$ & $32-35$ & $110-126$ & $86-102$ & $68-82$ \\
\hline & $19.2(1.06)$ & $7.3(0.40)$ & $7.0(0.40)$ & $49.5(0.96)$ & $33.5(0.92)$ & $119.0(5.42)$ & $94.9(4.80)$ & $74.0(5.10)$ \\
\hline \multicolumn{9}{|c|}{ Turdus amaurochalinus } \\
\hline$N \sigma ?$ & 2 & - & - & 2 & 2 & 2 & 2 & 2 \\
\hline Value/Range & 18.8 & - & - & $48.4-50.4$ & $32.5-35$ & 118 & $88-91$ & $64.5-68$ \\
\hline \multicolumn{9}{|c|}{ Geothlypis aequinoctialis } \\
\hline$N_{\sigma}$ & 1 & - & - & 1 & 1 & 1 & 1 & 1 \\
\hline Value/Range & 11.5 & - & - & 31.9 & 20.7 & 60 & 53 & 12.3 \\
\hline \multicolumn{9}{|c|}{ Basileuterus flaveolus } \\
\hline$N \sigma ?$ & 2 & - & - & 1 & 2 & 2 & 2 & 2 \\
\hline Value/Range & $11-12$ & - & - & 32.5 & $23.6-24$ & $64-65$ & $60-61$ & $13-18$ \\
\hline \multicolumn{9}{|c|}{ Pipraeidea melanonota } \\
\hline$N \varphi$ & 1 & - & - & 1 & 1 & 1 & 1 & 1 \\
\hline Value & 8.6 & - & - & 31.2 & 17.6 & 79 & 53 & 21 \\
\hline \multicolumn{9}{|c|}{ Dacnis cayana } \\
\hline$N \sigma$ & 1 & 1 & 1 & 1 & 1 & 1 & 1 & - \\
\hline Value & 14 & 5 & 4 & 32 & 17.5 & 66 & 42 & - \\
\hline$N$ ९ & 2 & 1 & 1 & 2 & 2 & 2 & 2 & 1 \\
\hline Value/Range & $13.1-14$ & 5 & 4.5 & $32-32.7$ & $17.4-18$ & $61-69$ & $36-45$ & 16.3 \\
\hline \multicolumn{9}{|c|}{ Thraupis sayaca } \\
\hline$N \sigma ?$ & 1 & 1 & 1 & 1 & 1 & 1 & 1 & 1 \\
\hline Value & 14 & 7.5 & 8 & 36 & 23.5 & 89 & 68 & 40 \\
\hline \multicolumn{9}{|c|}{ Neothraupis fasciata } \\
\hline$N \circ \odot a d$. & 5 & 5 & 5 & 5 & 5 & 5 & 5 & 2 \\
\hline Range & $14.5-16$ & $7-8$ & $8.5-9$ & $34-40$ & $22-28.5$ & $70-76$ & $64-69$ & $32-34$ \\
\hline Mean $(S D)$ & $15.5(0.71)$ & $7.4(0.40)$ & $8.8(0.30)$ & $36.0(2.30)$ & $24.9(3.20)$ & $72.4(2.60)$ & $65.9(1.90)$ & - \\
\hline$N$ o 9 juv. & 5 & 3 & 4 & 5 & 5 & 5 & 5 & 5 \\
\hline Range & $12.9-16$ & $7-8$ & $7-8$ & $34-37$ & $20-24.6$ & $69-74$ & $60-70$ & $27-38$ \\
\hline Mean $(S D)$ & $14.7(1.43)$ & - & - & $35.9(1.20)$ & $23.4(2.00)$ & $71.2(2.20)$ & $63.4(4.40)$ & $31.7(4.10)$ \\
\hline \multicolumn{9}{|c|}{ Cypsnagra hirundinacea } \\
\hline$N \circ ?$ & 2 & 2 & 2 & 2 & 2 & 2 & 2 & 1 \\
\hline Value/Range & $17-21$ & $16-17$ & 18 & $32-37$ & $23-24$ & $74-76.5$ & $64-66$ & 28 \\
\hline \multicolumn{9}{|c|}{ Saltator atricollis } \\
\hline$N \sigma ?$ & 2 & 2 & 2 & 2 & 2 & 2 & 2 & 1 \\
\hline Value/Range & $21-22$ & $10-11$ & $12-13$ & 44 & $26.5-30$ & $85-91$ & $91-95$ & 54 \\
\hline \multicolumn{9}{|c|}{ Coryphospingus cucullatus } \\
\hline$N \sigma \sigma$ & 10 & 6 & 6 & 9 & 10 & 10 & 10 & 7 \\
\hline Range & $10-13.5$ & $5-6.5$ & $6-7$ & $28.6-31$ & $17.4-21$ & $62.5-69$ & $52-63$ & $14-20$ \\
\hline Mean $(S D)$ & $11.6(0.95)$ & $5.9(0.50)$ & $6.8(0.40)$ & $29.6(0.90)$ & $18.7(1.60)$ & $64.8(2.00)$ & $58.9(3.50)$ & $16.7(3.06)$ \\
\hline$N$ ९ & 4 & 4 & 4 & 4 & 4 & 4 & 4 & 4 \\
\hline Value/Range & $10.9-13$ & 6 & $6.5-7$ & $28-29.7$ & $18-22.5$ & $55-66$ & $53-57$ & $15.1-16$ \\
\hline \multicolumn{9}{|c|}{ Oryzoborus angolensis } \\
\hline$N$ \% ९ & 2 & 2 & 2 & 2 & 2 & 2 & 2 & 1 \\
\hline Value/Range & $12-12.2$ & $8.5-9.1$ & 10.9-11.2 & $27.3-27.4$ & $16.8-17$ & 57 & 53 & 14.4 \\
\hline
\end{tabular}




\begin{tabular}{|c|c|c|c|c|c|c|c|c|}
\hline & $C$ & $B W$ & $B D$ & $H B$ & $T$ & Wing & Tail & Weight \\
\hline \multicolumn{9}{|c|}{ Sporophila caerulescens } \\
\hline$N \circ \sigma$ & 8 & 8 & 8 & 8 & 8 & 8 & 8 & - \\
\hline Range & $8.5-9.5$ & $5-7$ & $6.5-7.5$ & $22-23$ & $15-17$ & $50.5-60.5$ & $42.5-53$ & - \\
\hline Mean $(S D)$ & $9.0(0.27)$ & $5.6(0.80)$ & $6.9(0.30)$ & $22.8(0.40)$ & $16.1(0.70)$ & $56.9(2.10)$ & $48.5(2.70)$ & - \\
\hline$N$ ९ & 6 & 6 & 6 & 6 & 6 & 6 & 6 & - \\
\hline Range & $8.5-9.5$ & $5.5-6$ & $6.5-7$ & $22-24$ & $14-17$ & $50-54$ & $41-47$ & - \\
\hline Mean $(S D)$ & $9.0(0.58)$ & $5.8(0.30)$ & $6.8(0.30)$ & $22.7(0.80)$ & $15.4(1.10)$ & $52.3(1.80)$ & $44.7(2.20)$ & - \\
\hline \multicolumn{9}{|c|}{ Sporophila hypoxantha } \\
\hline$N \sigma$ & 1 & 1 & 1 & 1 & 1 & 1 & - & - \\
\hline Value & 9 & 5.5 & 6.5 & 22 & 14 & 50.5 & - & - \\
\hline$N ?$ & 1 & 1 & 1 & 1 & 1 & 1 & 1 & - \\
\hline Value & 8.5 & 5 & 6.5 & 22.5 & 14 & 50 & 41 & - \\
\hline \multicolumn{9}{|c|}{ Sporophila leucoptera } \\
\hline$N \sigma$ & 1 & 1 & 1 & 1 & 1 & 1 & 1 & - \\
\hline Value & 11 & 8 & 9 & 26 & 19.5 & 62 & 53.5 & - \\
\hline \multicolumn{9}{|c|}{ Volatinia jacarina } \\
\hline$N \sigma \sigma$ & 10 & 10 & 10 & 10 & 10 & 10 & 8 & 1 \\
\hline Value/Range & $10-11$ & $5-7$ & $5-7$ & $23-25$ & $14-18$ & $45-54$ & $41.5-49$ & 8 \\
\hline Mean $(S D)$ & $10.3(0.50)$ & $5.9(0.60)$ & $6.1(0.60)$ & $24.5(0.70)$ & $16.3(1.40)$ & $49.3(2.80)$ & $45.2(2.90)$ & - \\
\hline$N ?$ & 1 & 1 & 1 & 1 & 1 & 1 & 1 & - \\
\hline Value & 10 & 5 & 5 & 24.5 & 17 & 52 & 51 & - \\
\hline \multicolumn{9}{|c|}{ Emberizoides herbicola } \\
\hline$N$ o $९$ ad. & 2 & 3 & 3 & 3 & 3 & 3 & 3 & - \\
\hline Value/Range & $14-15$ & $6-7$ & 7 & $35.5-36$ & $25.5-27$ & $69-72$ & $105-113$ & - \\
\hline$N$ o 9 juv. & 1 & 1 & 1 & 1 & 1 & 1 & 1 & - \\
\hline Value & 12 & 6 & 6 & 33.5 & 26.5 & 66 & 67 & - \\
\hline \multicolumn{9}{|c|}{ Ammodramus humeralis } \\
\hline$N \sigma ?$ & 3 & 3 & 3 & 3 & 3 & 3 & 3 & 1 \\
\hline Value/Range & 12 & $5.5-7$ & $6-7$ & $28-29$ & $17.5-23$ & $55-61$ & $43-49$ & 15 \\
\hline \multicolumn{9}{|c|}{ Icterus pyrrhopterus } \\
\hline$N 9$ & 5 & - & - & 5 & 4 & 5 & 4 & 5 \\
\hline Range & $15.8-17$ & - & - & $38.6-40.5$ & $22.1-23.9$ & $84-95$ & $83-92$ & $24.5-30$ \\
\hline Mean $(S D)$ & $16.8(0.92)$ & - & - & $39.7(0.70)$ & - & $88.8(4.40)$ & - & $28.7(4.10)$ \\
\hline \multicolumn{9}{|c|}{ Molothrus rufoaxillaris } \\
\hline$N \sigma ?$ & 3 & 3 & 3 & 3 & 3 & 3 & 3 & 3 \\
\hline Range & $15-16$ & $8-9$ & $9-11$ & $34-38$ & $23-29$ & $110-122$ & $81-87$ & $55-60$ \\
\hline \multicolumn{9}{|c|}{ Gnorimopsar chopi } \\
\hline$N \sigma ?$ & 4 & 4 & 4 & 4 & 4 & 4 & 4 & 3 \\
\hline Range & $23-24$ & $7-11$ & $10.5-13$ & $48-51$ & $32-35$ & $120-127$ & $91-98$ & $48-74$ \\
\hline \multicolumn{9}{|c|}{ Euphonia chlorotica } \\
\hline$N \sigma$ & 1 & 1 & 1 & 1 & 1 & 1 & 1 & - \\
\hline Value & 8 & 6.5 & 4.5 & 24 & 14 & 56 & 32 & - \\
\hline$N ?$ & 1 & 1 & 1 & 1 & 1 & 1 & 1 & - \\
\hline Value & 7.5 & 5 & 4.5 & 24 & 14 & 55 & 35 & - \\
\hline
\end{tabular}


Small-billed Tinamou (Crypturellus parvirostris) (Tinamidae). Frequent resident in forest edge habitats at Laguna Blanca. The position of the nares is atypical and helps to distinguish the species in hand from the similar Tataupa Tinamou (C. tataupa). In the individual caught the nares were located $15 \mathrm{~mm}$ from the bill tip and 10 $\mathrm{mm}$ from the bill base. Bill measurements in the approximately "typical" location of the nares close to the bill base were $B W=7 \mathrm{~mm}, B D=6 \mathrm{~mm}$. According to Davies (2000), these measurements fall within the reference range of values for males.

Ash-throated Crake (Porzana albicollis albicollis) (Rallidae). Common resident in tall grassy vegetation on the lake shore. One individual of this species was captured in a Sherman trap for small mammals. Measurements are consistent with those of a large male according to data provided in Taylor and Van Perlo (1998).

Picui Ground-Dove (Columbina picui picui) (Columbidae). Common resident in anthropic habitats at Laguna Blanca.

Ruddy Ground-Dove (Columbina talpacoti talpacoti) (Columbidae). Common resident in anthropic habitats at Laguna Blanca. Measurements are consistent with those provided by Piratelli et al. (2001) for Mato Grosso do Sul (Brazil). An active nest of this species was found on 22 November 2005 at the base of the fronds of a small palm tree which also contained an active Social Flycatcher (Myiozetetes similis) nest (Smith 2006). One female captured on 31 July 2010 was moulting head and wings, and all except the central tail feathers were new. Another female on the same date was moulting wings and had completely new tail feathers.

Scaly Dove (Scardafella squammata squammata) (Columbidae). Common resident in anthropic habitats at Laguna Blanca but local in the rest of Paraguay. An active nest of this species was found in March 2009 (del Castillo pers. comm.).

Yellow-chevroned Parakeet (Brotogeris chiriri chiriri) (Psittacidae). Abundant resident in forest edge habitats at Laguna Blanca, with large flocks gathering in the mornings. Measurements are consistent with the upper end of the range given for this species in Juniper and Parr (1998), therein referred to as the Canary-winged Parkeet (B. versicolurus chiriri).

Dark-billed Cuckoo (Coccyzus melacoryphus) (Cuculidae). Common northern austral migrant in forest edge habitats at Laguna Blanca. Monotypic. The measurements of one individual caught differ slightly from a series of 20 Paraguayan specimens given by Payne (2005), but are only marginally outside the maximum and minimum range limits of his sample and two individuals from Mato Grosso do Sul (Brazil) reported by Piratelli et al. (2001). Payne's mean measurements were as follows: for males $(n=9)-C=22.3 \mathrm{~mm}, T=24.3 \mathrm{~mm}$, Wing $=117.9 \mathrm{~mm}$ and Tail $=135.6 \mathrm{~mm}$; for females $(n=11)-C=22.6 \mathrm{~mm}, T=24.0 \mathrm{~mm}$, Wing $=119.2 \mathrm{~mm}$ and Tail $=137.2 \mathrm{~mm}$.

Planalto Hermit (Phaethornis pretrei) (Trochilidae). Uncommon resident in anthropic and forest edge habitats at Laguna Blanca. Monotypic. According to Piratelli et al. (2001), the measurements for a single specimen from eastern Mato Grosso do Sul (Brazil) were as follows: $C=28 \mathrm{~mm}$, Wing $=60 \mathrm{~mm}$ and Tail $=70 \mathrm{~mm}$.

Gilded Sapphire (Hylocharis chrysura) (Trochilidae). Frequent resident in anthropic and forest edge habitats at Laguna Blanca. Monotypic. Measurements correspond closely with those of 3 individuals from eastern Mato Grosso do Sul (Brazil) (Piratelli et al. 2001). 
Glittering-bellied Emerald (Chlorostilbon lucidus lucidus) (Trochilidae). Frequent resident in anthropic and forest edge habitats at Laguna Blanca. Longer-winged (54 vs $49 \mathrm{~mm}$ ) and shorter-tailed (27 vs 31-31.5 mm) than individuals from Teniente Agripino Enciso National Park in Dry Chaco (Smith et al. 2008). Two unsexed individuals from eastern Mato Grosso do Sul (Brazil) had a wing of $49 \mathrm{~mm}$ and tail of 22 and $26 \mathrm{~mm}$, respectively, suggesting that these measurements were within the normal range for this species, therein referred to as Chlorostilbon aureoventris (Piratelli et al. 2001). Pacheco and Whitney (2006) presented arguments that the correct name of this species is $C$. lucidus.

Grey Potoo (Nyctibeus griseus griseus) (Nyctibiidae). Common resident in forested habitats, cerradón and open cerrado at Laguna Blanca, perching on tree stumps and fence posts. Cleere and Nurney (1998) recognised the subspecies N. g. cornutus for Paraguayan birds, but remarked that it was of questionable validity. Paraguayan specimens were placed in the nominate subspecies by Cohn-Haft (1999).

Little Nightjar (Caprimulgus parvulus parvulus) (Caprimulgidae). Common resident / partial migrant in forest edge habitats at Laguna Blanca. Measurements are consistent with those provided by Cleere and Nurney (1998) for the widespread nominate subspecies. Movements of this species are not well understood and abundance estimates are complicated by the seasonality of some vocalisations. The species is present year round at Laguna Blanca, but the apparent increase in its abundance during summer months is probably attributable to an influx of migratory birds.

Scissor-tailed Nightjar (Hydropsalis brasilianus furciferus) (Caprimulgidae). Common resident in campo sucio and cerradón at Laguna Blanca. Measurements are consistent with those provided by Cleere and Nurney (1998) for the large subspecies $H$. $b$. furciferus. One male captured 13 November 2005 showed damage to the tail and wing feathers suggesting a predatory attack. Considerable difference was noted in the colouration of the tail streamers in two other male birds. One bird had black streamers that were barred with rufous along the outer web, the other bird had the more typical colouration of black outer web tipped white and with white notches at the base and a completely white inner web. Tail measurements marked with an asterisk ${ }^{*}$ ) in Table 1 were as follows: outer feathers $-323-353 \mathrm{~mm}, 2^{\text {nd }}$ outer ones $-130-134$ $\mathrm{mm}$ and the central pair - $142 \mathrm{~mm}$. Handled birds frequently gape widely, and one bird gave a quiet throaty grunt whilst gaping.

White-winged Nightjar (Eleothreptus candicans) (Caprimulgidae). Extremely rare local resident in campo sucio cerrado at Laguna Blanca. Measurements are consistent with those provided by Cleere and Nurney (1998). At Laguna Blanca the species seems to be associated with wet, shallow, grassy valleys or fields dominated by the angiosperm plant Pouteria subcaerulea. However, the presence of these birds may be more related to the distribution of leks (which are apparently maintained for several years) rather than to specific habitat characteristics, as the individuals occur in quite different habitats in other areas of their Paraguayan range. They have also been seen foraging in agricultural land and amongst Eucalyptus plantations near Laguna Blanca. The White-winged Nightjar is a globally and nationally endangered and cerrado endemic species. 
Pauraque (Nyctidromus albicollis derbyanus) (Caprimulgidae). Common resident in humid forest and forest edge habitats at Laguna Blanca. N. a. derbyanus is one of the larger subspecies of the Pauraque and is the most southerly distributed. Measurements provided for a Laguna Blanca bird are consistent with the measurements given for N. a. derbyanus by Cleere and Nurney (1998).

White-barred Piculet (Picumnus cirratus pilcomayensis/cirratus) (Picidae). Uncommon resident in humid forest and forest edge habitats at Laguna Blanca. Measurements for a Laguna Blanca female are smaller than those given by Piratelli et al. (2001) for an unsexed individual of the subspecies P. c. cirratus in eastern Mato Grosso do Sul (Brazil) (Wing $=58 \mathrm{~mm}$, Tail $=36 \mathrm{~mm}$, Weight $=10 \mathrm{~g})$. Short (1982) notes that females of this species tend to be 1-2\% longer-winged and longer-tailed than males. Birds at Laguna Blanca correspond with the subspecies P. c. pilcomayensis as described by Winkler et al. (1995) in being distinctly greyish above and with red colouration restricted to the forecrown of males. However, the bold barring on the underparts is a characteristic of the nominate P. c. cirratus (Short 1982). Laguna Blanca may be in a zone of intergradation between these two subspecies.

Great Antshrike (Taraba major major) (Thamnophilidae). Rare resident in forest edge habitats at Laguna Blanca. There are no significant differences in measurements when compared to a male specimen from Teniente Agripino Enciso National Park in Dry Chaco (Smith et al. 2008) or to those provided by Piratelli et al. (2001) for Mato Grosso do Sul (Brazil). Weight is consistent with Alderete and Capllonch (2010) for birds from the northern Argentina.

Rusty-backed Antwren (Formicivora rufa rufa) (Thamnophilidae). Uncommon resident in scrubby forest edge habitats at Laguna Blanca. There are no significant differences in measurements when compared to those of unsexed specimens from Mato Grosso do Sul (Brazil) provided by Piratelli et al. (2001). This species is considered near threatened at the national level.

Rufous Hornero (Furnarius rufus paraguayae) (Furnariidae). Abundant resident in anthropic habitats at Laguna Blanca.

Pale-breasted Spinetail (Synallaxis albescens albescens) (Furnariidae). Rare resident at Laguna Blanca.

Narrow-billed Woodcreeper (Lepidocolaptes angustirostris angustirostris) (Furnariidae: Dendrocolaptinae). Frequent resident in forest and forest edge habitats at Laguna Blanca. Birds caught were generally similar in measurements to a sample of the subspecies L. a. certhiolus from the Dry Chaco at Teniente Agripino Enciso National Park (Smith et al. 2008) but somewhat shorter-winged (mean = 96.5 vs $97.25 \mathrm{~mm}$ ) and considerably lighter (25.8 vs $29.5 \mathrm{~g}$ ). However, both mean masses fall within the range for birds of the subspecies L. a. angustirostris from Mato Grosso do Sul (Brazil) (Piratelli et al. 2001) and Provincia Formosa in Argentina (Alderete and Capllonch 2010). Wing measurements provided by Piratelli et al. (2001) are consistent with the Laguna Blanca birds.

Southern Beardless-Tyrannulet (Camptostoma obsoletum obsoletum) (Tyrannidae). Frequent resident in forest edge, cerrado sensu stricto, cerradón and transitional forest habitats at Laguna Blanca. An individual caught on 31 July 2010 was in fresh plumage apart from slight head moult. The weight of this bird falls within the 
range for this subspecies from northern Argentina reported by Alderete and Capllonch (2010).

Lesser Elaenia (Elaenia chiriquensis albivertex) (Tyrannidae). Frequent breeding migrant in cerradón and cerrado sensu stricto at Laguna Blanca. Though widespread in a variety of habitats in the rest of the South American range, in Paraguay this species is closely associated with cerrado habitats.

Small-billed Elaenia (Elaenia parvirostris) (Tyrannidae). Frequent resident / partial migrant in scrubby forest edge habitats at Laguna Blanca. Monotypic. Mean wing and tail measurements are marginally smaller than lower range measurements provided by Piratelli et al. (2001).

Yellow-bellied Elaenia (Elaenia flavogaster flavogaster) (Tyrannidae). Common resident in forest edge and scrubby habitats at Laguna Blanca.

Tawny-crowned Pygmy-Tyrant (Euscarthmus meloryphus meloryphus) (Tyrannidae). Frequent resident in scrubby forest edge and cerrado sensu stricto at Laguna Blanca.

Pearly-vented Tody-Tyrant (Hemitriccus margaritaceiventer margaritaceiventer) (Tyrannidae). Common resident in scrubby forest edge habitats at Laguna Blanca. There are no significant differences in measurements as compared to those of unsexed specimens from Mato Grosso do Sul (Brazil) provided by Piratelli et al. (2001) or from Teniente Agripino Enciso National Park in the Dry Chaco (Smith et al. 2008). Weight range is consistent with those of birds from northern Argentina (Alderete and Capllonch 2010).

Bran-coloured Flycatcher (Myiophobus fasciatus flammiceps) (Tyrannidae). Frequent resident / partial migrant in scrubby forest edge habitats at Laguna Blanca. A bird caught on 18 August 2010 was in fresh plumage. Measurements of a single individual of the subspecies M. f. flammiceps from eastern Mato Grosso do Sul (Brazil) (Piratelli et al. 2001) were slightly larger than the maximum measurements for the Laguna Blanca sample. However, the percentage ratio of mean tail to wing lengths is similar $-89.3 \%$ in this study vs $83.8 \%$ given by Piratelli et al. (2001). Weight range is consistent with body masses of birds from northern Argentina (Alderete and Capllonch 2010).

Fuscous Flycatcher (Cnemotriccus fuscatus bimaculatus) (Tyrannidae). Uncommon resident / partial migrant in forest and forest edge habitats at Laguna Blanca. There are no significant differences in measurements when compared to those of unsexed specimens of the nominate subspecies from Mato Grosso do Sul (Brazil) provided by Piratelli et al. (2001).

Rufous Casiornis (Casiornis rufa) (Tyrannidae). Uncommon resident in cerradón, forest and forest edge habitats at Laguna Blanca. Monotypic. Two individuals caught on 20 July 2010 were in fresh plumage. There are no significant differences in measurements when compared to those of unsexed specimens from Mato Grosso do Sul (Brazil) provided by Piratelli et al. (2001). A single bird from Jujuy (Argentina) was slightly heavier (25.5 g) than our observed maximum (Alderete and Capllonch 2010).

Short-crested Myiarchus (Myiarchus ferox australis) (Tyrannidae). Uncommon resident in forest and forest edge habitats at Laguna Blanca. Wing measurements are consistent with a small male or typical female according to measurements given for 
the subspecies M.f. australis in Lanyon (1978). The tail to wing lengths ratio, however, is just $82.4 \%$, well below the range reported by Lanyon (92-104\%). A single individual of the same subspecies from eastern Mato Grosso do Sul (Brazil) had Tail $=85$ $\mathrm{mm}$ and Wing $=95 \mathrm{~mm}$, giving an intermediate ratio of 89.5\%. (Piratelli et al. 2001).

Brown-crested Myiarchus (Myiarchus tyrannulus tyrannulus) (Tyrannidae). Common resident in transitional forest and forest edge habitats at Laguna Blanca. An individual caught on 19 July 2010 had new primaries and tertials and showed signs of slight head and body moult. This bird was also exceedingly heavy at $42 \mathrm{~g}$, almost $30 \%$ heavier than published maximum body masses for this species (Lanyon 1978, Piratelli et al. 2001, Alderete and Capllonch 2010). Standard measurements were consistent with those published for southern populations of the nominate subspecies provided by Lanyon (1978).

Great Kiskadee (Pitangus sulphuratus argentinus /maximiliani) (Tyrannidae). Abundant resident in anthropic habitats at Laguna Blanca. Measurements are consistent with those provided by Piratelli et al. (2001) for the subspecies P. s. maximiliani from eastern Mato Grosso do Sul (Brazil). The presence of the subspecies P. s. argentinus in the southern Paraguay, however, makes subspecific designation of birds at Laguna Blanca difficult on currently available data. Nests of this species have been found during October and November (Smith 2006).

Social Flycatcher (Myiozetetes similis pallidiventris) (Tyrannidae). Frequent resident in forest edge and anthropic habitats at Laguna Blanca. An active nest of this species was found on 22 November 2005 placed along the frond stalk of a small palm tree, which also contained an active Ruddy Ground-Dove nest. This nest was close (within $20 \mathrm{~m}$ ) to a tree containing a Great Kiskadee nest. Although there was a considerable antagonism between the two flycatchers, neither of them paid attention to the activity of the doves (Smith 2006).

Band-tailed Manakin (Pipra fasciicauda scarlatina) (Pipridae). An individual, captured in scrubby vegetation at the edge of humid forest on 1 August 2010 was the first record of the species at Laguna Blanca. Measurements were consistent with those provided by Piratelli et al. (2001) from eastern Mato Grosso do Sul (Brazil). The bird was in fresh plumage.

American Cliff Swallow (Petrochelidon pyrrhonota pyrrhonota) (Hirundinidae). Uncommon transient at Laguna Blanca. This swallow is a Nearctic migrant and somewhat nomadic, its appearance in a given area is often related to "stormfollowing" behaviour. An exceptionally large flock of $c a 200$ individuals appeared on 13 December 2010 and took refuge from a large storm in the eaves of the boat house on the lake shore. The measured individual was captured in a hand net. Measurements and appearance were consistent with the subspecies $P$. p. pyrrhonota.

House Wren (Troglodytes aedon musculus) (Troglodytidae) - Abundant resident in anthropic habitats at Laguna Blanca.

Rufous-bellied Thrush (Turdus rufiventris rufiventris) (Turdidae) - Uncommon resident in humid forest and its edge at Laguna Blanca. Measurements are consistent with those provided for the nominate subspecies by Clement and Hathaway (2000).

Pale-breasted Thrush (Turdus leucomelas leucomelas) (Turdidae). Common resident in forest, forest edge and anthropic habitats at Laguna Blanca. Measurements 
are consistent with those provided for the nominate subspecies by Clement and Hathaway (2000) and Piratelli et al. (2001).

Creamy-bellied Thrush (Turdus amaurochalinus) (Turdidae). Frequent resident in forest, forest edge and anthropic habitats at Laguna Blanca. Monotypic. Measurements are consistent with those provided by Clement and Hathaway (2000). An individual caught on 26 July 2010 was in fresh plumage.

Masked Yellowthroat (Geothlypis aequinoctialis velata) (Parulidae). Uncommon transient in lakeside vegetation at Laguna Blanca, but common in marshlands in the surrounding area. Measurements are consistent with those provided for a large male of the subspecies G. a. velata by Curson et al. (1994).

Flavescent Warbler (Basileuterus flaveolus) (Parulidae). Frequent resident in transitional forest at Laguna Blanca. Monotypic. Measurements are consistent with those of two males provided by Curson et al. (1994) and with those from a large unsexed sample from eastern Mato Grosso do Sul (Brazil) (Piratelli et al. 2001). An individual caught on 26 July 2010 had worn wings and tail but showed no signs of moult. This species is considered near threatened at the national level.

Fawn-breasted Tanager (Pipraeidea melanonota melanonota) (Thraupidae). Rare resident / partial migrant in forest edge habitats at Laguna Blanca. Similar weights of 21.8 and $21.5 \mathrm{~g}$ were recorded for two males from Corrientes (Argentina) (Contreras 1983).

Blue Dacnis (Dacnis cayana paraguayensis) (Thraupidae). Frequent resident in forest and forest edge habitats at Laguna Blanca. A female caught on 31 July 2010 was in fresh plumage.

Sayaca Tanager (Thraupis sayaca sayaca) (Thraupidae). Frequent resident in forest, forest edge and anthropic habitats at Laguna Blanca. Wing, culmen and tail measurements of a Laguna Blanca bird are within the range for birds from Mato Grosso do Sul, but tarsus and weight are approximately 30 and 15\%, respectively, greater than maximum measurements provided by Piratelli et al. (2001).

Shrike-like Tanager (Neothraupis fasciata) (Thraupidae). Common resident in cerrado sensu stricto and campo sucio at Laguna Blanca. Monotypic. Netted adults called loudly and frequently attracted other flock members into the net. Juveniles were captured frequently in Sherman traps set for small mammals. This is a globally near threatened and nationally vulnerable species. Although not considered a cerrado endemic by da Silva (1997) this species is known from just four localities in Paraguay, all in cerrado areas (Guyra Paraguay 2005).

White-rumped Tanager (Cypsnagra hirundinacea hirundinacea) (Thraupidae). Common resident in cerradón and campo sucio at Laguna Blanca. This species is considered vulnerable at the national level. Although not considered a cerrado endemic by da Silva (1997) this species is local in Paraguay and closely-associated with cerrado habitats.

Black-throated Saltator (Saltator atricollis) (Cardinalidae). Common resident in cerradón, campo sucio and cerrado sensu stricto at Laguna Blanca. Monotypic. This is a cerrado endemic species.

Red-crested Finch (Coryphospingus cucullatus rubescens) (Emberizidae). Abundant resident in all habitats at Laguna Blanca. Measurements are consistent with 
a large unsexed sample of subspecies C. c. rubescens from eastern Mato Grosso do Sul (Brazil) (Piratelli et al. 2001).

Lesser Seed-Finch (Oryzoborus angolensis angolensis) (Emberizidae). Uncommon resident in forest edge habitat at Laguna Blanca. An individual caught on 29 July 2010 was in fresh plumage. Measurements are marginally smaller than limits given by Piratelli et al. (2001). However, the percentage ratio of the mean tail to wing length is almost identical $-93 \%$ in this study vs $93.3 \%$ in Piratelli et al. (2001).

Double-collared Seedeater (Sporophila caerulescens caerulescens) (Emberizidae). Seasonally abundant resident in forest edge, campo sucio and cerrado sensu stricto at Laguna Blanca. Numbers increase during the passage of mixed flocks of Sporophila species during late October and November.

Tawny-bellied Seedeater (Sporophila hypoxantha) (Emberizidae). Uncommon transient / passage migrant in scrubby lakeside vegetation at Laguna Blanca. Monotypic. This species has been recorded only during the passage of mixed flocks of Sporophila species during late October and November.

White-bellied Seedeater (Sporophila leucoptera leucoptera) (Emberizidae). Uncommon transient in scrubby lakeside vegetation at Laguna Blanca. This species has been recorded only during the passage of mixed flocks of Sporophila species during late October and November. However, it is an uncommon resident throughout much of the eastern Paraguay, its association with these flocks is not migratory.

Blue-black Grassquit (Volatinia jacarina jacarina) (Emberizidae). Abundant resident in forest edge, campo sucio and cerrado sensu stricto at Laguna Blanca. Measurements provided by Peris (1990) for this species are clearly in error.

Wedge-tailed Grassfinch (Emberizoides herbicola herbicola) (Emberizidae). Common resident in campo limpio and campo sucio cerrado at Laguna Blanca. The mean lenght of the shortest tail feather was $53.8 \mathrm{~mm}(50.5-57.0, \pm 4.60)$ in adults and $48 \mathrm{~mm}$ in a single juvenile.

Grassland Sparrow (Ammodramus humeralis xanthornus) (Emberizidae). Abundant resident in campo limpio and campo sucio cerrado at Laguna Blanca. A ground nest $($ diameter $=95 \mathrm{~mm}$, cup diameter $=60 \mathrm{~mm})$ with 3 eggs $(19.5 \times 14 \mathrm{~mm})$ of this species was found on 2 November 2005.

Variable Oriole (Icterus pyrrhopterus pyrrhopterus) (Icteridae). Uncommon resident in humid and transitional forest, forest edge and anthropic habitats at Laguna Blanca. The southern populations of the Epaulet Oriole (I. cayanensis) were split from Amazonian birds by D'Horta et al. (2008) with the name Variable Oriole (I. pyrrhopterus) taking priority. Measurements are consistent with those provided for the subspecies I. p. pyrrhopterus by Jaramillo and Burke (1999) and with the measurements of a single individual from Teniente Agripino Enciso National Park by Smith et al. (2008). Peris (1990) provided similar mean weight data of $30 \mathrm{~g}( \pm 2)$ for four unsexed specimens of "Icterus cayannensis" from the Paraguayan Humid Chaco. One individual caught on 20 July 2010 was moulting its tail. The primaries were old and the inner two secondaries fresh, but it showed no signs of body moult. Another bird caught on the same day had fresh wing feathers.

Screaming Cowbird (Molothrus rufoaxillaris) (Icteridae). Common resident in anthropic habitats at Laguna Blanca. Monotypic. Measurements are consistent with 
those provided by Jaramillo and Burke (1999). This species is often considered an obligate nest parasite, but the typical host of this species, the Greyish Baywing (Agelaioides badius), does not occur at Laguna Blanca. Chopi Blackbird (Gnorimopsar chopi) is the substitute host in this area and juveniles are often seen amongst flocks of that species. Although the host species also occurs in cerrado, adults of this species, and to date all cases of parasitism, have been observed only in anthropic habitats. Similar substitution of hosts has been reported in Paraná (Brazil) by Sick (1993) and in Iguazú National Park, Misiones (Argentina) by Fraga (1996).

Chopi Blackbird (Gnorimopsar chopi chopi) (Icteridae). Common resident in cerradón, campo sucio cerrado and anthropic habitats at Laguna Blanca. Measurements are consistent with those provided for the nominate subspecies by Jaramillo and Burke (1999).

Purple-throated Euphonia (Euphonia chlorotica serrirostris) (Fringillidae). Common resident in forest and forest edge habitats at Laguna Blanca. A pair with a flightless fledgling that had recently left the nest was observed on 20 January 2011.

\section{ACKNOWLEDGEMENTS}

Thanks to Malvina Duarte, the owner of the Reserva Natural de Laguna Blanca, for her continued support of Para La Tierra Biological Station and the scientific studies that are performed there. Bryan Wainwright, John Smit, Alex Mead and Hemme Batjes accompanied us in the field for parts of the fieldwork.

\section{REFERENCES}

Alderete C., Capllonch P. 2010. Pesos de Aves Suboscines de Argentina. Nótul Faun. 2a Ser. 58: $1-12$.

Cleere N., Nurney D. 1998. Nightjars: A Guide to Nightjars and Related Nightbirds. Pica Press, Sussex.

Clement P., Hathaway R. 2000. Thrushes. Christopher Helm, London.

Coconier E.G. 2004. Project Conservation of the Paraguayan Cerrado. Guyra Paraguay, Asunción.

Cohn-Haft M. 1999. Family Nyctibiidae (Potoos). In: del Hoyo J. (Ed.) Handbook of the Birds of the World. vol 5. Lynx Ed., Barcelona.

Colli G.R., Bastos R.P., Araújo A.F.B. 2002. The Character and Dynamics of the Cerrado Herpetofauna. In: Oliveira P.S., Marquis R.J. (Eds). The Cerrado of Brazil: Ecology and Natural History of a Neotropical Savanna. Columbia Univ. Press, New York.

Conservation International Online. 2011. The Biodiversity Hotspots. www.biodiversityhotspots.org/xp/hotspots/cerrado/Pages/default.aspx. Consulted online February 2011.

Contreras J.R. 1983. Notas Sobre el Peso de Aves Argentinas III. Hist. Nat. 3: 95-96.

Corrêa A.N.S. 1990. Pecuária de Corte no Brasil Central. EMBRAPA, Campo Grande.

Curson J., Quinn D., Beadle D. 1994. New World Warblers. Christopher Helm, London.

da Silva J.M.C. 1997. Endemic Bird Species and Conservation in the Cerrado Region, South America. Biodivers. Conserv. 6, 3: 535-450. DOI: 10.1023/A:1018368809116

Davies S.J.J.F. 2000. Ratites and Tinamous. Oxford Univ. Press, Oxford.

de Oliveira F.A., Sfredo G.J., de Castro C., Klepker D. 2007. Fertilidade do Solo e Nutriçăo da Soja. EMBRAPA Circ. Téc. 50. 
D’Horta F.M., da Silva J.M.C., Ribas C.C. 2008. Species Limits and Hybridization Zones in Icterus cayannensis-chrysocephalus Group (Aves: Icteridae). Biol. J. Linn. Soc. 95: 583-597. DOI: $10.1111 / \mathrm{j} .1095-8312.2008 .01059 . \mathrm{x}$

Eiten G. 1972. The Cerrado Vegetation of Brazil. Bot. Rev. 38, 2: 201-341.

Eiten G. 1978. Delimitation of the Cerrado Concept. Vegetatio 36, 3: 169-178.

FAUNA Paraguay. 2011. FAUNA Paraguay Checklist of the Birds of Paraguay. www.faunaparaguay.com/listbirds.html. Consulted online February 2011

Fraga R.M. 1996. Further Evidence of Parasitism of Chopi Blackbirds (Gnorimopsar chopi) by the Specialized Screaming Cowbird (Molothrus rufoaxillaris). Condor 98: 866-867.

Guyra Paraguay 2005. Atlas de las Aves del Paraguay. Gyura Paraguay. Asunción: 212 pp.

Guyra Paraguay 2008. Áreas Importantes para la Conservación de las Aves del Paraguay. Guyra Paraguay / BirdLife International Asunción.

IUCN 2011. IUCN Red List of Threatened Species. www.iucnredlist.org.

Jaramillo A., Burke P. 1999. New World Blackbirds. Christopher Helm, London.

Juniper T., Parr M. 1998. Parrots: A Guide to the Parrots of the World. Pica Press, Sussex.

Lanyon W.E. 1978. Revision of the Myiarchus Flycatchers of South America. AMNH Bull. 161, article 4.

Myers N., Mittermeier R.A., Mittermeier C.G., Fonseca G.A.B., Kent J. 2000. Biodiversity Hotspots for Conservation Priorities. Nature 403: 853-858. DOI: 10.1038/35002501

Nogueira C., Valdujo P., França F.G.R. 2005. Habitat Variation and Lizard Diversity in a Cerrado Area of Central Brazil. Stud. Neotrop. Fauna Environ. 40, 2: 105-112. DOI: 0.1080/01650520500129901

Pacheco J.F., Whitney B.M. 2006. Mandatory Changes for the Scientific Names of Three Neotropical Birds. BOC Bull. 126, 3: 242-244.

Payne R.B. 2005. The Cuckoos. Oxford Univ. Press, Oxford.

Peris S.J. 1990. Peso y Biometría de Algunas Aves del Chaco Húmedo (Presidente Hayes, Paraguay). Ornitol. Neotrop. 1: 31-32

Piratelli A.J., de Melo F.P., Caliri R.F. 2001. Dados Morfométricos de Aves de Sub-bosque da Regiăo Leste de Mato Grosso do Sul. Rev. Bras. Zool. 18: 305-317.

Short L.L. 1982. Woodpeckers of the World. Delaware Mus. Nat. Hist., Monogr. Ser. 4, Greenville.

Sick H. 1993. Birds in Brazil. Princeton Univ. Press, New Jersey.

Silveira L., de Almeida Jácomo A.T., Rodrigues F.H.G., Diniz Filho J.A.F. 1999. Impact of Wildfires on the Megafauna of Emas National Park, Central Brazil. Oryx 33, 2: 108-114. DOI: 10.1046/j.1365-3008.1999.00039.x.

Smith P. 2006. Interspecific Aggression in Nesting Great Kiskadees (Pitangus sulphuratus) in Paraguay. Boletin SAO 16: 67-70.

Smith P., Betuel A., Batjes H. 2008. Weights and Morphometrics of Dry Chaco Birds from Teniente Agripino Enciso National Park, Departamento Boquerón. Bellbird 3.

Smith P., del Castillo H., Batjes H., Montiel M., Wainwright B. 2005. An Avifaunal Inventory of Estancia Laguna Blanca, Departamento San Pedro, Northeastern Paraguay. FAUNA Paraguay Tech. Publ. 2, consulted online at www.faunaparaguay.com/lagbla.rep.pdf

Svensson L. 1984. Identification Guide to European Passerines. Stockholm, Sweden.

Taylor B., Van Perlo B. 1998. Rails: A Guide to the Rails, Crakes, Gallinules and Coots of the World. Christopher Helm, London.

Whittle C.L. 1927. A Plea for More Bird Weighers. Northeast. Bird-Banding Assoc. Bull. 3, 3: 75.

Winkler H., Christie D.A., Nurney D. 1995. Woodpeckers: A Guide to the Woodpeckers, Piculets and Wrynecks of the World. Pica Press, Sussex. 